\title{
Apple and Pear Scab Ontology
}

\author{
Imants Zarembo \\ Institute of Engineering \\ Rezekne Academy of Technologies \\ Rezekne, Latvia \\ imants.zarembo@rta.lv \\ Olga Sokolova \\ Unit of Plant Pathology and \\ Entomology, \\ Institute of Horticulture, \\ Latvia University of Agriculture \\ Dobele, Latvia \\ olga.sokolova@llu.lv
}

\author{
Artis Teilans \\ Institute of Engineering \\ Rezekne Academy of Technologies \\ Rezekne, Latvia \\ artis.teilans@rta.lv \\ Lienite Litavniece \\ The Research Institute for Business \\ and Social Processes \\ Rezekne Academy of Technologies \\ Rezekne, Latvia \\ lienite.litavniece@rta.lv
}

\author{
Toms Bartulsons \\ Unit of Genetics and Breeding, \\ Institute of Horticulture, Latvia \\ University of Agriculture \\ Dobele, Latvia \\ toms.bartulsons@llu.lv
}

\author{
Anna Nikolajeva \\ Faculty of Engineering \\ Rezekne Academy of Technologies \\ Rezekne, Latvia \\ anna.nikolajeva@rta.lv
}

\begin{abstract}
An important issue in horticulture is ensuring plant disease, such as scab, prevention and treatment. Apple and pear are among the most widely grown (approximately $43 \%$ of all fruit tree area [1]) and economically important fruit crops specified worldwide and in Latvia. Scab diseases caused by ascomycetous fungi Venturia inaequalis and V.pyrina are economically the most important diseases worldwide. Research projects have produced research data covering various aspects of plant-pathogen interactions, but there is no internal linkage analysis, as well as implementation of other types of data (such as environmental and meteorological data, etc.). Establishing such a data integration system would allow the identification of new regularities in plant-pathogen interactions, and provide mechanisms for disease control decisions. Semantic analysis is one of information technology approaches to finding relationships in data. The product of analysis is ontology. There are plant disease ontologies which provide classification of diseases and describe their reasons. However, there is no ontology which describes a specific plant and relations among its farming parameters and disease probability. Such an ontology for apple and pear scab is presented in this paper. The constructed ontology can be applied to develop guidelines or digital expert systems.
\end{abstract}

Keywords - ontology, pathogens, scab

\section{INTRODUCTION}

Apple scab caused by Venturia inaequalis (Cooke) G. Winter and European pear scab caused by Venturia pyrina Aderh are one of the most important diseases of the apple and European pear growing regions worldwide [2] especially in regions with cool and wet spring and early summer [3]. Scab is considered as one of the most serious threats to commercial apple and pear production especially in organic orchards, causing severe reduction in the quality and size of fruits, premature fruit drop, defoliation and reduction of tree vigor over time [4].

Venturia inaequalis and $V$. pyrina are Ascomycetes fungus with the life cycle of them comprised of one sexual and multiple asexual reproductions annually, which causes significant variations in the fungus population. Annual sexual reproduction leads to recombination and high variation in fungal genome and changes in population genetic structure.

Species of Venturia are mostly identified based on morphology and host [5] and on the basis of ribosomal internal transcribed spacer (ITS) sequence data [5], [6], [7], [8]. Often for species identification of fungi used include the ITS region of ribosomal DNA genes (ITS1 and ITS2), the small and large subunits of the nuclear ribosomal RNA genes (SSU and LSU), and also three protein coding genes, namely translation elongation factor-1 alpha (TEF1) and the largest and second largest subunits of the RNA polymerases II (RPB1, RPB2) [7], [9].

Genetic variation and population structure of $V$. inaequalis were studied more than population and genetic diversity of $V$. pyrina. Different molecular tools are used to characterize genetic diversity of populations of $V$. inaequalis in various apple producing countries. Molecular markers such as random amplified polymorphic DNA (RAPDs) [10], restriction fragment length polymorphisms 
(RFLPs), amplified fragment length polymorphisms (AFLPs) [11], and simple sequence repeat markers (SSRs) have been used to determine genetic diversity of $V$. inaequalis isolates from different regions of the world [2], [12], [13], [14].

Also, assessment of the level of scab intra-population variability was carried out on the basis of studying the variability of signs of its monosporous isolate colour and texture of the main air mycelium and the central tubercle. On the morphological and cultural characteristics were identified 34 morphotypes of $V$. inaequalis isolates [15], [16].

Rapid evolution of pathogens and emergence of new races of fungi that overcome the resistance genes in the host and also fungicides that leads to problems in the control of the disease. During the course of coevolution, apple has evolved mechanisms to prevent the severity of scab. The isolates of $V$. inaequalis evoke variable symptoms on different apple cultivars [17], [18] which depend on resistance (R) genes. Currently only one major resistance gene Rvp1 of European pear resistance to scab is identified [19], 15 apple resistance genes are known [20].

Several studies have been conducted on the biology and diversity of $V$. inaequalis, the causative agent of the apple scab on the world, but there are relatively few studies on the racial composition and genetic diversity of the pear scab, $V$. pyrina. Systematic research on the racial composition and population diversity of $V$. inaequalis and $V$. pyrina in Latvia was launched in 2010 and a lot data has been collected by now to help characterize the diversity of pathogen populations and to find out the race composition, as this would allow predicting the aggressiveness of pathogens and the formation of new races. Due to the large amount and variety of data semantic analysis can be applied to organize, trace patterns and to find relationships between data. The product of analysis is ontology. An ontology defines a common vocabulary for sharing the information in a specific domain. It contains definitions of basic concepts in the domain and relations among them. Such an ontology for apple and pear scab is presented in this paper. This is the first time an ontology is used for characteristics of diversity on $V$. inaequalis and $V$. pyrina populations in Latvia. Data used for development of ontology is based on processed data from the Institute of Horticulture. The aim of the constructed ontology is to be applied to develop guidelines or digital expert systems.

\section{MATERIALS AND METHODS}

\section{A. Related Work}

There are plant disease ontologies which provide classification of diseases and describe their reasons. Following best practices principles existing ontologies were analysed to identify whether they can be reused when building the apple and pear scab ontology.

Plant-Pathogen Interactions Ontology (PPIO) [21] is an ontology that describes plant-pathogen interactions and offers a scaffold into which important domain data can be embedded in a precise and computationally-transparent manner. PPIO is being developed from a plant-pathogen interaction point of view, and intends to describe all biological features related to this process. In [22] authors design a system and an ontology for identifying rice diseases from a human observation. The resulting ontology represents abnormalities of rice diseases in terms of symptoms, colours, shapes, and infected plant parts. The Crop Ontology (CO) [23] current objective is to compile validated concepts along with their inter-relationships on anatomy, structure and phenotype of Crops, on trait measurement and methods as well as on Germplasm with the multi-crop passport terms. Plant Stress Ontology [24] describes biotic and abiotic stresses that a plant may encounter. The abiotic stress class has two subclasses: plant stress caused by an excess or deficiency of some element. The biotic stress class has two child terms, herbivory stress and plant disease.

\section{B. Development Overview}

The analysis of the existing ontologies was followed by the development of the apple and pear scab ontology. Ontology development process differs with each ontology. To ensure quality and reliability of the developed ontology a development methodology should be followed. Agile Methodology for Ontology Development (AMOD) [25] was selected for the purposes of this research. AMOD aims to bridge the gap between ontology engineering and software engineering by adopting the agile principles and practices in ontology development. AMOD classifies the ontology development into three phases: pre-game, development and post-game. The pre-game phase includes the identification of the ontology goal and scope, tools and techniques, competency questions and available information sources. Outcomes of the pre-game phase for Apple and Pear Scab ontology are summarized in Table 1.

TABLE I. OUTCOMES OF THE PRE-GAME PHASE

\begin{tabular}{|l|l|}
\hline Item & Outcome \\
\hline Domain & Apple and pear scab \\
\hline Goal & $\begin{array}{l}\text { Finding relationship among data from research } \\
\text { projects that have produced data covering various } \\
\text { aspects of plant-pathogen interactions. }\end{array}$ \\
\hline Scope & $\begin{array}{l}\text { Domain knowledge for processing research data of } \\
\text { Institute of Horticulture. }\end{array}$ \\
\hline $\begin{array}{l}\text { Tools and } \\
\text { techniques }\end{array}$ & WebProtégé, Protégé, OWL 2 language \\
\hline $\begin{array}{l}\text { Knowledge } \\
\text { sources }\end{array}$ & Interviews with domain experts, research data \\
\hline
\end{tabular}

Development phase consisted of two 4-week sprints: two iterations of development. Sprint planning sessions resulted in a set of tasks the development team decided to complete in the sprint. During the knowledge acquisition activities domain experts were interviewed in order to capture all the relevant terms related to the field of interest (concepts, properties, relations, etc.). Institute of Horticulture research data was analysed informally to extract relevant information. The research data consisted of 
different apple and pear cultivars, their resistance genes such as Vf gene, Vm gene, cultivar location in the research field and location in Latvia, weather data, and pathogen morphological traits, pathogen genetic markers, isolate identification data, and field data from cultivar and pathogen interaction from different years.

Ontology was built on existing data from the Institute of Horticulture. The rose family (Rosaceae) served as a basis, where two genera (apples and pears) were selected from this family. The Ontology was constructed in such a way that it could be supplemented with other genera of the rose family, whose research is being carried out at the Institute of Horticulture. This division was based on the principles of the taxonomy of species. The next class was the breakdown of the cultivars of each species, with the cultivars at the Institute of Horticulture, and cultivars from around Latvia were used. The "Research subject" and "Research object" classes were divided into subclasses according to the research directions used in the institute, such as: plants, bacteria, and fungi. Since one cultivar will have several trees in the research field, then the Institute of Horticulture field tree-finding system, based on blocks, rows, and the position of trees in a row, was introduced. Information on the pathogen was described from existing studies on morphological parameters [15], [16] as well as genetic parameters. For research on genetics of plants and pathogen parameters, databases known in the industry, such as GeneBank, CBS Fungal Biodiversity Centre were used. Information on the isolates was developed on a data recording system used by the Institute of Horticulture, which shows the origin of the isolate, what type of field type it was, and what genetic markers have been identified, such as ITS [26], [27], TEF [7], [9], and TUB genes [27], [28]. Both Latvian and English terms are industry specific.

Conceptualization activities resulted in a conceptual model of the ontology represented in the form of relationship diagrams (see Fig.1.)

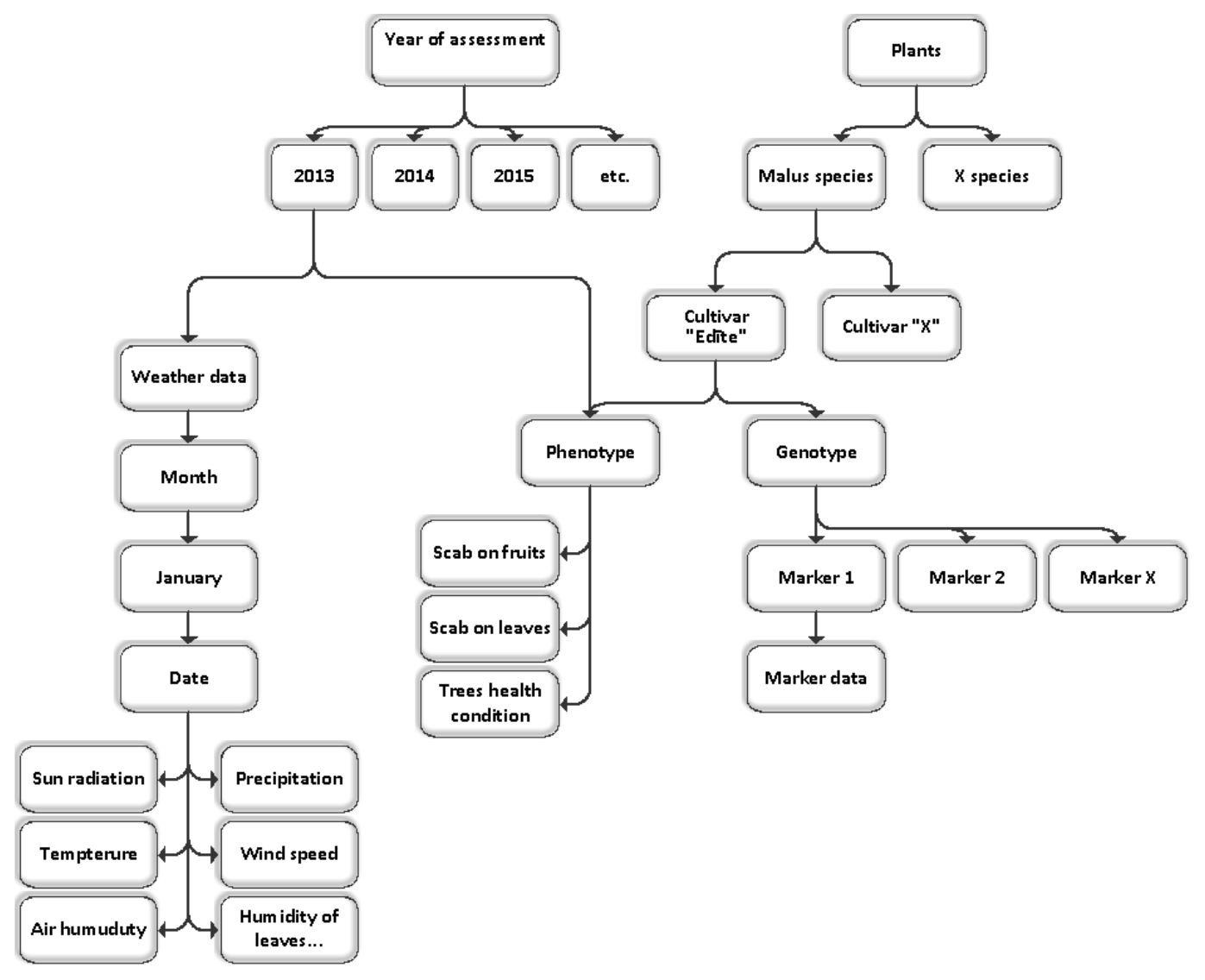

Fig. 1. Ontology conceptual model diagram example.

Formalization activities consisted of building a formal ontology based on conceptual model diagrams using WebProtégé ontology editor. WebProtégé was a tool of choice when building the ontology because WebProtégé is a free, open-source collaborative ontology development environment for the Web. This tool allowed domain experts and ontology engineers to work hand in hand, building the ontology collaboratively. The ontology was developed using OWL 2 Web Ontology Language. OWL 2 ontologies provide classes, properties, individuals, and data values and are stored as Semantic Web documents. The ontology was developed to support two languages: Latvian and English. At the end of each sprint the development team presented 
the results to the project team and compared them to the plan set up in sprint planning.

HermiT reasoner supported by Protégé was used postgame to infer new information from the ontology and to ensure consistency. Reasoner revealed two types of new knowledge: 1 . new and previously undefined relations between concepts; 2. new and incorrect relations which highlighted underlying errors in ontology structure and which were later corrected.

\section{RESULTS AND DISCUSSION}

The team of ontology engineers and domain experts have developed Apple and Pear Scab Ontology which will be applied in the development of digital apple and pear scab disease expert system and will serve as a basis for apple and pear scab prevention guidelines. Fig. 3. shows collapsed ontology class hierarchy as seen in WebProtégé.

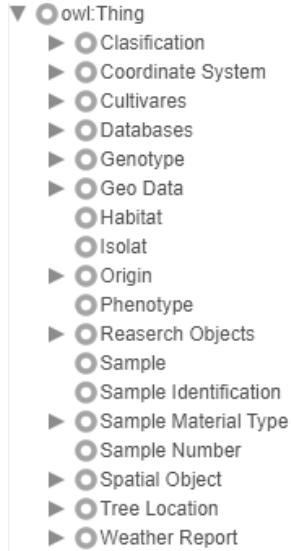

Fig. 3. Ontology class hierarchy.

The developed ontology consists of 70 classes, 49 object properties, 59 data properties and 611 individuals. Ontology entities are annotated using rdfs:comment annotation properties to provide context. The list of individuals contains individuals of apple and pear cultivars occurring in research data, and their isolates. An example of isolate individual entity graph is shown in Fig. 2.

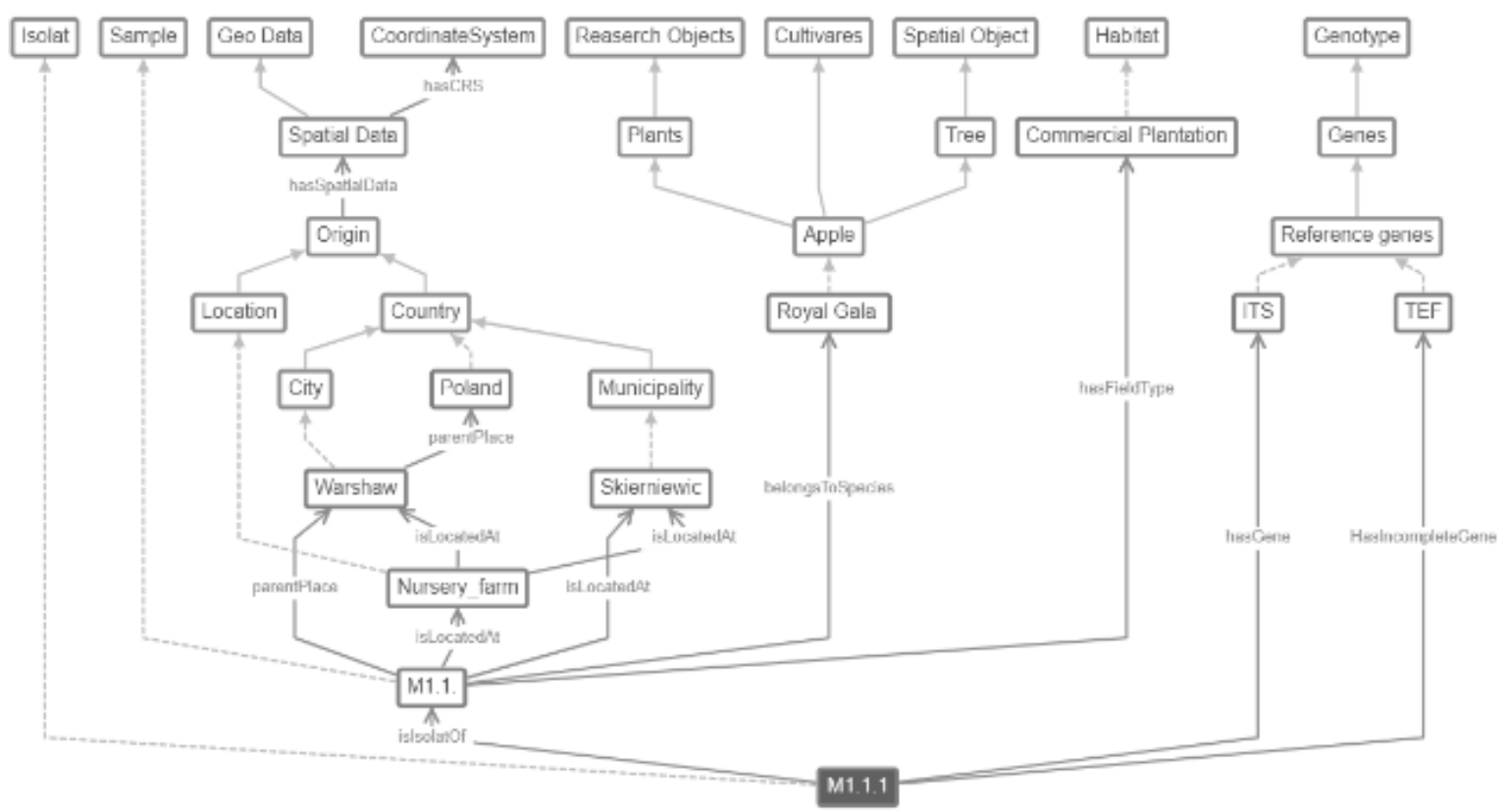

Fig. 2. An example of ontology individual entity graph.

The Sample data were collected from Institute of Horticulture data and added to the new ontology. For instance, in the ontology class "Family" were added the Rosaceae for pears and apples, and for the pathogens Venturiaceae for Venturia inaequalis and V.pyrina. The ontology class "Genus” consisted of several Malus sp. used in research at Institute of Horticulture. Likewise, several Malus pathogens were added to this class. Furthermore, 32 apple cultivars and 2 pear cultivars were added in the ontology. Additionally, five commonly used databases for pathogen identification and gene identification were added in the class "Databases". Four most used gene regions were added. In addition, several habitat types were added in the class "Habitat". For example, home gardens, commercial plantations, and collection gardens. Data from isolate samples were stored in the class "Isolate" therefore, more than 400 isolates were added. In addition, several locations 
for the used samples were added. As a result, the ontology was populated with 611 individual data points.

\section{CONCLUSIONS}

The ontology provides a significant first step towards collecting all data from different research directions such as cultivar breeding evaluation, meteorological data, genetic research, and pathogen research and combining in a single data system. Furthermore, adding the existing data set from earlier studies will extend the existing ontology. This ontology can be helpful in finding new links, the interaction between apple scab caused by Venturia inaequalis and Malus sp. cultivars, the resistance mechanics in cultivars, and the effect of weather on scab population changes. These results emphasize the importance of combining field and laboratory research data with ontologies to find properties and the relations between them. The method for building an ontology used here can be applied to different plant species, genera, and families with different pathogens. This is a fundamental area to be explored further.

The developed Apple and Pear Ontology will be updated with new individuals based on the latest research data of the Institute of Horticulture as it becomes available. In the future authors plan to publish the ontology in open access.

\section{ACKNOWLEDGMENTS}

Funding institution: Latvian Council of Science.

Funding number: lzp-2019/1-0094.

\section{Acronym: FLPP-2019-1.}

This research is funded by the Latvian Council of Science, project "Application of deep learning and data mining for the study of plant-pathogen interaction: the case of apple and pear scab”, project No. lzp-2019/1-0094.

\section{REFERENCES}

[1] Fruit trees and berry bushes (including strawberries) (2016). Central Statistical Bureau. [Online]. Available: http://data.csb.gov.lv/pxweb/en/lauks/lauks_03Augk_ikgad/LA G070.px/?rxid=ce8aac91-f2b0-4f13-a25d-29f57b1468fb, [Accessed: 15.03.2021.]

[2] I. Tenzer, C. Gessler, Subdivision and genetic structure of four populations of Venturia inaequalis in Switzerland. Eur J Plant Pathol. 1997; 103: pp. 565-571.

[3] W. E. MacHardy, Apple scab: biology, epidemiology, and management. APS Press: St. Paul, Minnesota. 1996.

[4] L. Gao, A. Berrie, J. Yang, X. Xu, Within- and between-orchard variability in the sensitivity of Venturia inaequalis to myclobutanil, a DMI fungicide, in the UK. Pest Manag Sci. 2009; 65: pp. 1241-1249.

[5] C. Stehmann, S. Pennycook, K.M. Plummer, (2001). Molecular identification of a sexual interloper: the pear pathogen, Venturia pirina, has sex on apple. Phytopathology, 91, pp. 633-641.

[6] G. Schnabel, E. L. Schnabel and A. L. Jones, Characterization of ribosomal DNA from Venturia inaequalis and ITS phylogenetic relationship to rDNA from other tree-fruit Venturia species, 1998.

[7] A. Beck, A. Ritchel, K. Schubert, U. Braun, and D. Triebel 2005. Phylogenetic relationship of the anamorphic genus Fusicladium s. lat. as inferred by ITS nrDNA data. Mycol. Prog. 4: pp. 111-116.
[8] J. K. Bowen, C. H. Mesarich, V. G. M. Bus, R. M. Beresford, K. M. Plummer, and M. D. Templeton, Venturia inaequalis: The causal agent of apple scab. Mol. Plant Pathol., 2011, 12: pp. 105122.

[9] C. L. Schoch, K. A. Seifert, S. Huhndorf et al, Nuclear ribosomal internal transcribed spacer (ITS) region as a universal DNA barcode marker for Fungi. Proccedings of the National Academy of Sciences of the USA, Vol. 109 (16), 2012, pp. 6241 - 6246.

[10] I. Tenzer, and C. Gessler, Genetic diversity of Venturia inaequalis across Europe. Eur. J. Plant Pathol., 1999, 105: pp. 545-552.

[11] X. Xu, J. Yang, V. Thakur, A. Roberts, D. J. Barbara, Population variation of apple scab (Venturia inaequalis) isolates from Asia and Europe. Plant Disease, Vol. 92(2), 2008, pp. 247- 252.

[12] P. Gladieux, X. Zang, D. Afoufa-Bastien, R. V. Sanhueza, M. Sbaghi, and B. Le Cam, On the Origin and spread of the scab disease of apple: Out of central Asia. PLoS One 3:e1455, 2008. https://doi.org/10.1371/journal.pone.0001455 Crossref, Medline, ISI, Google Scholar.

[13] F. Guérin, P. Franck, A. Loiseau, M. Devaux, and B. Le Cam. Isolation of 21 new polymorphic microsatellite loci in the phytopathogenic fungus Venturia inaequalis. Mol. Ecol. Notes 4: pp. 268-270, 2004.

[14] X. Xu, N. Harvey, A. Roberts, and D. Barbara, Population variation of apple scab (Venturia inaequalis) within mixed orchards in the UK. Eur. J. Plant Pathol. 135: pp. 97-104, 2013.

[15] А. И. Насонов, Г.В. Якуба, Е. В. Лободина, Особенности морфотипного состава популяции Venturia inaequalis (Cooke) G. Winter на восприимчивых к парше сортах яблони // Плодоводство и ягодоводство России. Т. 58.C. pp. 151-157, 2019.

[16] А. И. Насонов, Особенности морфолого -культуральных особенностей аскоспоровых изолятов возбудителя парши яблони. Научные труды СКЗНИИСиВ, Том 9, с. 187- 192, 2016.

[17] M. Chevalier, Y. Lespinasse, S. Renaudin, A microscopic study of different classes of symptoms coded by the Vf gene in apple for resistance to scab (Venturia ineaqualis) Plant Pathology, 1991;40: pp. 249-256.

[18] C. Gessler, A. Patocchi, S. Sansavini, S. Tartarini, L. Gianfranceschi, Venturia inaequalis resistance in apple. Critical Reviews in Plant Sciences. 2006;25(6): pp. 473-503.

[19] L. Bouvier, M. Bourcy, M. Boulay, M. Tellier, P. Guérif, C. Denancé, C. Durel, Y. Lespinasse, A new pear scab resistance gene Rvp1 from the European pear cultivar 'Navara' maps in a genomic region syntenic to an apple scab resistance gene cluster on linkage group 2. Tree Genetics \& Genomes, Vol. 8, Issue 1, pp. 53- 60, 2011.

[20] V. G. M. Bus, E. H. A. Rikkerink, V. Caffier, C. E. Durel, K. M. Plummer, Revision of the nomenclature of the differential host pathogen interactions of Venturia inaequalis and Malus. Annual Review of Phytopathology, No. 49, pp. 391-413, 2011.

[21] D. M. Dooley, E. J. Griffiths, G. S. Gosal et al., FoodOn: a harmonized food ontology to increase global food traceability, quality control and data integration. npj Sci Food 2, 23, 2018. https://doi.org/10.1038/s41538-018-0032-6

[22] W. Jearanaiwongkul et al., An Ontology-based Approach to Plant Disease Identification System, IAIT, pp. 1-8, 2018.

[23] Crop Ontology Curation Tool. [Online]. Available: http://www.cropontology.org/ [Accessed: 12.03.2021.]

[24] GitHub - Planteome/plant-stress-ontology: An ontology containing biotic and abiotic plant stresses. [Online]. Available: https://github.com/Planteome/plant-stress-ontology [Accessed: 16.03.2021.]

[25] S. Abdelghany et al., An Agile Methodology for Ontology Development. International Journal of Intelligent Engineering and Systems, Vol.12, No.2, 2019. DOI: 10.22266/ijies2019.0430.17 
[26] G. Schnabel, E. L. Schnabel and A. L. Jones, Characterization of ribosomal DNA from Venturia inaequalis and ITS phylogenetic relationship to rDNA from other tree-fruit Venturia species, 1998.

[27] T. A. Koopman, J. C. Meitz-Hopkins, A. E. Bester-van der Merwe, K. R. Tobutt, C. Bester, C. L. Lennox, Genetic diversity and gene flow of four South African Venturia inaequalis (apple scab) populations. Phytopathology, Vol. 107, pp. 455- 462, 2017.

[28] H. A. Raja, A. N. Miller, C. J. Pearce and N. H. Oberlies, Fungal identification using molecular tools: a primer for the natural products research community. Journal of natural products, Vol. 8, No. 3, pp. 756-770, 2017. 